\title{
Community-Based Tourism - Option for Forest-Dependent Communities in 1A IUCN Protected Areas? Cameroon Case Study
}

\author{
Shelley Burgin ${ }^{1}$, Eric Fru Zama ${ }^{2}$ \\ ${ }^{1}$ Faculty of Society \& Design, Bond University, Gold Coast, Queensland, Australia, 4229 \\ ${ }^{2}$ P.O.Box 1190, Bamenda, Mankon, North West Region, Cameroon
}

\begin{abstract}
In developing countries, 'exponential' growth in IUCN protected lands has occurred in the last 25 years. Approximately $6 \%$ of protected areas are 'Strict Nature Reserve[s]' (1A) with emphasis on conservation and strict restrictions on human access. Before Bakossi Forest Reserve (Cameroon) had 1A protection, 95\% of local families used the Reserve for their livelihood. They farmed cash crops, collected fire wood, timber, and food with incomes equivalent to US\$35,000/annually/family. Post-protection, the Reserve's local communities lacked support to develop alternative livelihoods, and $75 \%$ reported being intercepted illegally trespassing by Reserve guards. Without illegal activity economic impacts would have been substantially greater. Protection has also meant foregone national income from timber and coffee exports. We used Bakossi Forest Reserve as a case study to identify issues facing local communities excluded from the Reserve that traditionally provided their livelihood. We also investigated potential alternative family livelihoods based on critical evaluation of the literature. We identified 'exceptional' community-based tourism potential. We also found that Cameroon was the first African country to develop community-based forestry with the dual roles of conservation and poverty alleviation. Using this model, community-based tourism could be a cost-effectively initiative to deliver the same dual roles as community-based forestry.
\end{abstract}

\section{Introduction}

Globally, over extended periods of history, conserving areas for their natural values has been widespread. While such lands were protected for a range of reasons (e.g., Royal hunting, protection of ecosystem services, recreation, scenic values [1], religion, culture [2]), many now fall within the contemporary protected area categories of the International Union for the Conservation of Nature (IUCN; see Table 1). Globally, this protected area network already occupied approximately 13.0\% of the total land surface (oceans, $0.7 \%$ ) before 2010. Of these, almost $6.0 \%$ of the terrestrial environment $(0.65 \%$ oceans) was protected under the strictest IUCN category available (Ia) for biodiversity conservation [3,4]. Combined, this network of protected areas represents the world's largest ever planned land use [5,6]. However, most of this protected area network has been gazetted within the last 50 years [4]. Particularly in developing countries, their numbers have risen exponentially in the last 25 years [7], and Dudley and Parrish [9] suggested that it was likely that reservation of new protected areas would continue into the future.

Despite this history of preservation of nature that extended back into antiquity $[1,2]$, there was no developed international nomenclature for protected areas before 1933. The first international criteria 
developed that attempted to elucidate protected area terminology occurred in association with the International Conference for the Protection of Flora and Fauna (1933). The outcome was the development of four categories of protected areas - 'national park', 'strict nature reserve', 'fauna and flora reserve', and 'reserved with prohibition for hunting and collecting' [8]. Subsequently, in 1942, at the Western Hemisphere Convention on Nature Protection and Wildlife Preservation, four categories were identified - 'national park', 'national reserve', 'nature monument', and 'strict wilderness reserve' [10]. In 1962 a World List of National Parks and Equivalent Reserves was presented to the First World Conference on National Parks on behalf of the newly formed Commission of National Parks and Protected Areas [11]; however, it was not until the Second World Parks Congress (1972) that there was a call for the development of an international nomenclature, and agreed definitions for each category developed [12]. Based mainly on management objectives, in 1978 the IUCN proposed 10 categories; however, shortly thereafter inherent issues with the system were identified including weaknesses in the nomenclature. A revised system, based on categories I-V and a modification of category VIII were used as the basis for the development of the nomenclature that was adopted by the IUCN General Assembly meeting in Buenos Aires in 1994 [9]. This resulted in the first international definition of a 'protected area': An area of land and/or sea especially dedicated to the protection and maintenance of biological diversity, and of natural and associated cultural resources, and managed through legal or other effective means [13] with accompanying criteria for 6 categories of protected area.

Table 1. The six categories of protected areas of the International Union for the Conservation of Nature [5]

Category Type Characteristics

\begin{tabular}{|c|c|c|}
\hline Ia & $\begin{array}{l}\text { Strict Nature } \\
\text { Reserve }\end{array}$ & $\begin{array}{l}\text { Biodiversity protection and/or geomorphological features. } \\
\text { Emphasis on conservation values with human access/use strictly } \\
\text { controlled and limited. }\end{array}$ \\
\hline $\mathrm{Ib}$ & $\begin{array}{l}\text { Wilderness } \\
\text { Area }\end{array}$ & $\begin{array}{l}\text { Typically largely unmodified areas that retain their natural } \\
\text { character/influence without permanent or significant human } \\
\text { habitation. Protected and managed to preserve their natural } \\
\text { condition. }\end{array}$ \\
\hline II & National Park & $\begin{array}{l}\text { Protection of large-scale ecological processes, species and } \\
\text { ecosystem characteristics of area. Also provides foundation for } \\
\text { environmentally/culturally compatible spiritual, scientific, } \\
\text { educational, recreational, and visitor opportunities. }\end{array}$ \\
\hline III & $\begin{array}{l}\text { Natural } \\
\text { Monument or } \\
\text { Feature }\end{array}$ & $\begin{array}{l}\text { Protect specific natural monument including landform, sea } \\
\text { mount, submarine cavern, geological feature (e.g., cave) or living } \\
\text { feature (e.g., ancient grove). }\end{array}$ \\
\hline IV & $\begin{array}{l}\text { Habitat/Species } \\
\text { Management } \\
\text { Area }\end{array}$ & $\begin{array}{l}\text { Protection of particular priority species or habitat of which many } \\
\text { may need regular active intervention to address target } \\
\text { species/habitat requirements. }\end{array}$ \\
\hline $\mathrm{V}$ & $\begin{array}{l}\text { Protected } \\
\text { Landscape }\end{array}$ & $\begin{array}{l}\text { Areas where interaction of people and nature has produced an } \\
\text { area of distinct character with significant ecological, biological, } \\
\text { cultural and scenic value, and where safeguarding the integrity of } \\
\text { this interaction vital to protecting/sustaining the area and } \\
\text { associated values. }\end{array}$ \\
\hline VI & $\begin{array}{l}\text { Protected areas } \\
\text { with } \\
\text { sustainable use } \\
\text { of natural } \\
\text { resources }\end{array}$ & $\begin{array}{l}\text { Conservation of ecosystems/habitats, together with associated } \\
\text { cultural values and traditional natural resource management } \\
\text { systems. Generally large and mostly in natural condition with } \\
\text { proportion under sustainable natural resource management with } \\
\text { low-level non-industrial use of natural resources compatible with } \\
\text { nature conservation. }\end{array}$ \\
\hline
\end{tabular}


Dudley [8] reported that the 'key principles' of the 1994 guidelines were that protected areas were categorised primarily on management objectives, assignment to a category did not reflect the level of perceived management effectiveness, that while the categories were internationally designated, they could be varied nationally, all categories were considered important, and a gradation in human intervention was implied. Research on the use and performance of these guidelines was undertaken by Bishop et al. [14]. Their amended guidelines led to the recommendation for a greater governance dimension for IUCN protected areas at, for example, at world congresses in 2003 and 2004. Ultimately, the World Commission on Protected Areas Categories Task Force was formed and a new set of guidelines was developed [8]. After extensive consultation (see e.g., Dudley [8] for outline), a modified definition of protected areas was developed: A clearly defined geographical space, recognised, dedicated and managed, through legal or other effective means, to achieve the long-term conservation of nature with associated ecosystem services and cultural values [5. p. 8].

Despite issues, some of which had been addressed within the contemporary guidelines, in 2008 Dudley [8] suggested that protected areas currently constituted the best approach to protecting biodiversity, and that they were also progressively being recognised as vital ecosystem services in terms of 'genetic warehouses'. He also suggested that 'protected area enforcement represents a unique environmental commitment to the future, and a beacon of hope in what sometimes seems to be a depressing slide into environmental and social decline'. It was further suggested that where people are allowed to continue to live and/or use the areas for their livelihood, protected areas may serve to protect threatened human communities or sites of great cultural and spiritual value. Indeed, one of the accompanying principles of the contemporary definition is that the definition and categories of protected areas should not be used as an excuse for dispossessing people of their land' [14]. However, particularly in developing countries, there has been limited evidence that, in practice, protected area management has effectively safeguarded the culture and traditions of the people who have historically lived in and around protected areas. There is also a lack of evidence that protected area enforcement contributes substantially to local community needs [15]. In this paper we use Bakossi Forest Reserve (Cameroon) as a case study to demonstrate the issues that can be associated with the conservation of lands for the protection of nature under the classification of 'Strict Nature Reserve' (category Ia; see Table 1) when the land has previously been inexplicitly linked to the livelihood of local communities.

\section{Strict Nature Reserve Classification}

Lands listed under IUCN Ia category are set aside explicitly to protect nature and also, on occasions, geological/geomorphological features. In such areas human visitation, use and impacts are strictly controlled and limited to ensure protection of nature (see Table 1). Reservation of such areas indicates that they are considered important reference areas for scientific research and monitoring. The primary objective of lands under the Ia category is for the conservation of outstanding ecosystems, species and/or geodiversity features that have developed mostly (or completely) without human forces, and that could be degraded or destroyed if there was more than 'light' human impacts [14]. The concept is, therefore, to maintain areas as close to undisturbed by recent humans activity as possible; to retain areas where human access is excluded for all except research and environmental monitoring while minimising human disturbance; and that the primary objective for the land's conservation is for its ecological conservation [16]. However, the creation of protected areas under this category are often characterised by the reservation of significant portions of land and/or water that have been traditionally used by indigenous communities for their livelihood [17], and include areas that the local indigenous peoples have historically reserved for religious and cultural purposes [2]. One such Reserve is the Bakossi Forest Reserve of Cameron which was officially declared a 'Strict Nature Reserve' (IUCN-Category Ia Protected Area) in 2000. In 2008 this Forest Reserve was gazetted by Prime Ministerial Decree. To comply with the international declaration of this site, and to maintain its status as such, the Cameron government considered it necessary to place a ban on all forms of human exploitation within the Reserve, and this included excluding the traditional owners from occupying or using the area for their livelihood. 


\section{The Bakossi Forest Reserve, Cameroon}

Cameroon has vast natural ecological areas, many of which have IUCN protection status that include world heritage sites, forest reserves, and national parks. The Bakossi Forest Reserve, protected as a 'Strict Nature Reserve' (Ia) under IUCN classification, is considered one of the most important (Table 2) of the more than 100 protected areas of Cameroon [18]. This Forest Reserve is within the Bakossi Mountains, a chain of mountains that include Kupe-Muanenguba and Mungo Divisions of Southwest Cameroon, and encompasses the largest cloud forest in Western-Central Africa. It covers an estimated 5,517 sq. $\mathrm{km}(551,700 \mathrm{ha})$, and is located in the South West Region of Cameroon $\left(4^{\circ} 44^{\prime} 34^{\prime \prime} \mathrm{N}, 9^{\circ}\right.$ $\left.35^{\prime} 20^{\prime \prime} \mathrm{E}\right)$ [15]. Covered in dense tropical rainforest, the Forest Reserve is sufficiently rich in plant and animal diversity to be considered a 'key' site for biodiversity within the Bakossi Mountains [19]. Of particular interest are the many primates, birds and plant species of the area, most of which are endemic to Mount Kupe. To date 2,412 plant species have been described from the Forest Reserve of which 82 are endemic [20,21] and 232 of these plant species are listed in the Red Data List as threatened with extinction [19]. There are also more than 329 bird species within the Mount Kupe area of the Forest Reserve and these include the Malaconotus kupeensis Mount Kupe bushshrike, the endangered Kupeornis gilberti white-throated mountain babbler, and the vulnerable Malaconotus gladiator green-breasted bushshrike and Picathartes oreas grey-necked Picathartes [22]. The area is also home to the 'healthiest' remaining populations of the endangered Mandrillus leucophaeus drill, a primate closely related to the Mandrillus sphinx mandrill. This species lives in groups ranging in size from five to $4000 \mathrm{~m}$ across altitudes and habitats from the lowlands through pre-montane at $2000 \mathrm{~m}$ where they live in montane forests and savannah habitats [15, 22, 23]. Although heavily exploited by hunters into the 1970s, with the efforts of the Traditional Chiefs the drill was protected in 1994, subsequently the population has begun to recover. Other primates of the area include the Preuss monkey (Cercopithecus preussi), collared mangabey (Cercocebus torquatus), red-eared Guenon (Cercopithecus erythrotis), and greater spot-nosed monkey (Cercopithecus nictitans), together with several taxa of bush baby (Galago spp.) and chimpanzee [22].

Apart from local, national and international organisations (e.g., Regional Centre for Conservation and Development, Kew Royal Botanic Gardens, World Wide Fund for Nature), the management of the Forest Reserve is the responsibility of the Cameroon Government through the Ministry of Forest and Wildlife. This government department is charged with enforcing the implementation of the 1994 Forestry and Wildlife Law [15]. However, due to practical challenges, including lack of staff, financial and material resources, management of the protected area is inhibited [26]. For example, Lambi and Ndenecho [15] monitored the activities of the forest officers charged with managing the Reserve's forest resources and found that officers spent over half of their time (57.\%) 'policing and guarding' the Forest Reserve which left limited time for other management activities.

This substantial time spent policing, in part, reflects the high level of illegal activity that occurs in the Forest Reserve. This is partly because, as occurs in many developing countries, prior to reservation of Bakossi Forest Reserve as an Ia category Strict Nature Reserve, the life of local communities was inexplicitly intertwined with the forest which provided the local people with the resources for their livelihood (e.g., farming, fishing, hunting, collection of medical plants, firewood, timber, non-timber products) [27]. For example, Djeukam [25] estimated that there were nearly four million people, predominantly belonging to the Bantu and Pygmy ethnic groups in the South and East regions of Cameron that depended entirely on the forest for their livelihood and, therefore, the quality and survival of the forest has been critical to their own economic, social, biological, and cultural survival. To these people, the forest was their 'Gross Domestic Product' until it was reserved as a Strict Nature Reserve. In addition, they also used such areas for recreation and spiritual renewal. With the reservation of the land as a category Ia Protected Area, the people are no longer legally allowed to access these traditional lands and, as with most developing countries, no adequate alternative has been provided for the people who have been disposed of their lands, and thus deprived of direct access to their traditional livelihoods. With much, if not all, of their livelihood taken from them, the people tend to resist conservation initiatives and, we suggest, typically have no alternative but to continue their 
known way of life illegally. However, the full economic impact of the loss of resources on the community with the establishment of the protected area, as has occurred in the Bakossi community in Cameroon, is usually not known [25].

Table 2. Major protected areas of Cameroon, year of first gazettal, size, and their International Union for the Conservation of Nature (IUCN) category [18, 24, 25]

\begin{tabular}{llll}
$\begin{array}{l}\text { Date } \\
\text { first } \\
\text { created }\end{array}$ & Name & IUCN Category & Size (ha) \\
\hline \multirow{2}{*}{1932} & Bénoué National Park & & \\
& Douala Edea Wildlife Reserve & II-National Park & 180,000 \\
& Faro National Park & IV-Habitat/Species Management Area & 160,000 \\
& Mozogo-Gokoro & II-National Park & 330,000 \\
1933 & Kalfou Wildlife Park & II-National Park & 1,400 \\
1934 & Takamanda Forest Reserve & II-National Park & 4,000 \\
& Waza National Park & Ia- Strict Nature Reserve & 67,599 \\
1941 & Rumpi Hills Wildlife Reserve & II-National Park & 170,000 \\
1947 & Bouba-Ndjida National Park & VI-Protected Area & 45,843 \\
& Kalamaloue National Park & II-National Park & 220,000 \\
1950 & Dja Reserve & II-National Park & 4,500 \\
1956 & Bakossi Forest Reserve & IV-Habitat/Species Management Area & 526,000 \\
1962 & Korup National Park & Ia-Strict Nature Reserve & 551,700 \\
1964 & Kimbi Forest Reserve & II-National Park & 126,000 \\
& Mbi Crater & IV-Habitat/Species Management Area & 5,600 \\
1968 & Santchou Forest Reserve & Ia- Strict Nature Reserve & 400 \\
2000 & Boumba Bek Park & IV-Habitat/Species Management Area & 7,000 \\
& Campo Wildlife Park & II-National Park & 210,000 \\
& Lobeke Wildlife Park & II-National Park & 271,000 \\
& Mbam et Djérem & II-National Park & 43,000 \\
& Mbayang Mbo Game Sanctuary & II-National Park & 416,512 \\
& Mengame Gorilla Sanctuary & IV-Habitat/Species Management Area & 48,500 \\
& & IV-Habitat/Species Management Area & 17,500 \\
& & & \\
\hline
\end{tabular}

Apart from the loss of livelihoods, people typically lose their natural heritage, including land and property, especially when they are relocated. Dudley et al. [5] described the phenomenon as 'a mounting concern', especially where the allocation of protected areas is being used as an excuse to relocate indigenous people from their natural inheritance. In the process, families may be separated, and people lose access rights to important ancestral sites. This is because protection of such areas always changes land tenure and thus sources of household income, which typically results in inequality in the distribution of benefits, especially amongst the poorest and least influential families in the community. As a result economic and sociocultural linkages are broken in most communities that have been evicted from reserves. In addition, once the forest is protected and the traditional owners are excluded, there tends to be a divergence in the relationship between forest users and their forest compared to when it was not protected. This demonstrates that effective biodiversity conservation programs based on protected areas should primarily take into account the traditional owners who have historically managed the forest for their livelihood. This idea is not new. Community participation in development and conservation programs dates back to, at least, the 1980s when governments, national and international organisations involved in natural resource management articulated the need to involve indigenous communities in the planning, development, and conservation programs when areas were targeted for protection. This requirement has been nearmandatory for a long period [28] although participation alone seems inadequate since most 
community members often think that their participation is equivalent to stripping themselves of the rights to their ancestral heritage. The meeting point between protecting the forest and using the forest as a means of livelihoods is, therefore, crucial for the success of conservation programs based on protection of lands.

Although the rationale for conserving nature through reservation of lands as protected areas is laudable and cannot be overlooked; however, there is growing concern that the costs are mostly incurred by the local people who rely on the available resources from the area reserved for their livelihoods [29]. Typically, the social and economic welfare of the traditional owners is seriously compromised with changes in land tenure, and the loss of their source of household income. Sharpe [28] suggested that the key to environmental management was for those seeking to conserve areas for conservation to ensure that they articulate their aspirations within the context of those of the local interests and values.

\section{Response of Local Communities to Protection of Bakossi Forest Reserve}

During the establishment phase, the local people of Bakossi Forest Reserve actively participated in delineating the boundaries, and the effectiveness of the Forest Reserve management improved between 2003 and 2007. After 2007; however, those considered to lack education and awareness of the environmental goals of the Forest Reserve were excluded leading to failures $[15,30]$. Ebua et al. [31] suggested that such failure to integrate local people into the longer term management of the Bakossi Forest Reserve undermined conservation efforts. For example, in a survey of villagers who had historically relied on the Forest Reserve for their livelihood, Zama [32] found that any negative or ambiguous reaction from respondents to the Forest Reserve did not arise from opposition to the idea of conservation of the land. This lack of opposition to conservation was also much more widely articulated by the large contingent of indigenous, mobile and local communities gathered from across the world at the $5^{\text {th }}$ World's Park Congress [33].

It has been suggested [34] that social cohesion is a major consideration when local communities are faced with the establishment of protected areas on their lands. More than half of the respondents to the survey of Zama [32] indicated that apart from changing their hunting and farming habits, the establishment of the Forest Reserve had not significantly changed their cultures and traditions since their shrines continued to be protected and there had been no restriction on them performing their traditional rights in the Forest Reserve provided their activities did not result in changes to the landscape or composition of the biodiversity of the area. This indicates that the major issues that the local communities had with the Strict Nature Reserve protection was with the impact on their livelihood.

The most important activities carried out within the lands now reserved as a Forest Reserve included farming (e.g., cocoa, coffee, oil palm, maize), and collection of nuts, medicine, bush meat, fire wood, and timber. A self-assessment by local villagers of the loss of resources due to exclusion from their lands with the reservation of a Strict Nature Reserve was equivalent to US\$35,000/annually. All cocoa and coffee produced was sold and the combined income represented at least $75 \%$ of the total household income of respondents. The majority of the food crops (e.g., maize, cassava, beans, cocoyams) produced were also sold [32]. Fonchingong [35] also reported that most of the food produced was to earn money for other needs (e.g., education, health, social activities).

Zama [32] reported that $95 \%$ of respondents said that their families had depended heavily on the Forest Reserve for livelihood before the Reserve was gazetted as an Ia Protected Area, and that local villages claimed that they had lost access to between 6-10 hectares of productive land with their exclusion from the Forest Reserve. This was deemed sufficient to destabilise the local economy because there was a lack of alternative opportunities to supplement their livelihood. For example, almost all of those questioned replied that the protected status of the area had affected their families negatively, and over $85 \%$ said that it was very difficult to obtain the resources they required for their day-to-day livelihood without access to the Forest Reserve. However, approximately $75 \%$ of those 
interviewed said they did not know the boundaries of the Forest Reserve, and were thus presumably unaware of whether they were illegally using the area or not, and approaching $40 \%$ said that they ignored the restrictions on the use of the lands and continued to undertake their normal activities within the Forest Reserve. This indicates that there is widespread illegal use of the lands. For example, over $75 \%$ of those interviewed admitted to having been chased by forest guards within the Forest Reserve and had the goods that they had collected in the forest confiscated. The declaration of the Bakossi Forest Reserve has, therefore, resulted in substantial numbers in the local community continuing to use the Forest Reserve. Without the illegal use of the area there would have been a destabilising effect on the local economy because of the lack of alternative opportunities to supplement their livelihood. With the loss of access to the Forest Reserve, local villagers have become trespassers on lands they previously used for their livelihood.

\section{The Way Forward}

The issues associated with the gazettal of Bakossi Forest Park as a Strict Nature Reserve, and the associated dispossession of the people of their legal livelihood is by no means an isolated incidence. Redford and Fearn [36] reported that many of the strict protection regimes that have been imposed on protected areas that have entailed the world's highest biodiversity areas are failing. They further suggested that the international community had begun to realise that inhibiting the access of the local people to these areas could be impractical, unaffordable, and ethically questionable. For example, at the World Park's Congress held in Durban in 2003, the 5,000 participants adopted a 'new paradigm' that acknowledged the need to respect the rights of local communities. The Accord recognised the sovereignty of local people over forest areas that they considered part of the public domain, and their role in determining management regimes. However, despite more than a decade having passed since the Congress and the declaration [37], and the principles underpinning the contemporary definition of biodiversity including an explicit statement that such protection should not be used as an excuse to dispossess people from their lands [see 14], people continue to be excluded from their traditional lands in the guise of biodiversity conservation. For example, Redford and Fearn [36] suggested that recent proposals that have dealt with the expansion of protected areas frequently do not include consideration of the impacts on local people, and typically did not consider alternatives. They reiterated that when implementing protected areas, there was a need to provide livelihood opportunities for the people, particularly indigenous peoples, living in and around them, and that this approach could be compatible with the goals of environmental services protection and biodiversity conservation.

Without such input, it was suggested that the strict protection regimes required to ensure long term protection of biodiversity would fail [36]. It is, therefore, inevitable that developing countries, such as Cameroon, would fail without substantial outside support. This is because, as Wilkie and Carpenter $[38$, p. 332] asserted, in 'debt-ridden, high-population-growth, resource-mining states of the Congo Basin ... [including Cameroon] conservation of biodiversity is seldom the primary concern of national policy makers or of local resource users'. They go on to point out that the recurring costs of managing protected areas and the lost opportunity costs of alternative land uses (e.g., logging, farming, mining) represent a substantial net drain on local and national economies. The result of substantial underfunding results in 'progressive ecological impoverishment' due to lack of effective management [39]. In addition, as demonstrated in Bakossi Forest Reserve, the outcome of protection of the environment has served to destabilise the local economy because of a lack of alternative opportunities to supplement those who have been excluded from the land and thus their livelihood [32].

In poor developing countries the funds to manage major areas of land of high conservation value are limited and, in addition, by protecting the lands substantial funds that could potentially be obtained by logging, cropping and/or mining such areas are unrealised. As indicated above, in Bakossi Forest Park, as occurs in a large number of areas reserved for biodiversity conservation across the developing world, the local people who used the area for their livelihood are particularly disadvantaged with the protection of their lands for biodiversity conservation. One alternative that is often suggested is that the local communities develop community-based tourism incorporating nature and/or cultural tourism. 
Indeed tourism has been historically described as 'manner from heaven' [40, p. 1) although, the potential weaknesses of tourism as a development strategy has been widely recognised. Despite the negatives, developing countries often perceive tourism as playing a key role in their economic development strategies [41].

While the average growth rate of tourism in sub-Saharan Africa countries has been increasing [46], the scale of development has differed widely from 'embryonic' to countries with well developed, 'vigorous tourism sectors' (Dieke, 2003). A major reason for poor performance of some countries of the Region is their inability to position, adequately promote, and market themselves as desirable community-based tourism (nature-based and/or cultural) destinations. For example, it has only been in the last decade that Cameroon has committed substantial financial resources to the development of destination marketing and tourism branding [42]. Such marketing and development has to be undertaken within the context of sustainability, accompanied by development within other sectors of the economy and the general infrastructure base [42, 43], including transportation, accommodation and tourist safety. However, in Cameroon, tourism development is limited by government budgetary constraints that inhibit the development of new sites while small-scale businesses also have limited ability to access capital. Airfares (both internationally and regionally) are expensive, and ground transportation and some accommodation facilities are of 'poor quality'. However, it has been suggested that more could be achieved if there was a stronger commitment to tourism and its marketing and development [44]. This has occurred in more recent years [42, 45] although the reality is that with limited resources, it has been considered unrealistic to think that the Cameroon government's finances could allow for the development of tourism to the extent that the protected areas would be self-sustaining in the near future [39]. Although figures are scarce, in 1998 Culverwell [46] reported that Cameroon contributed \$US143,325 of the estimated \$US1,901,893 required for the personnel and equipment needed to manage its current protected area network in an effective manner.

Although Cameroon has 'exceptional' tourism potential due to its cultural and natural attributes [44], it is clearly beyond the capacity of the government to develop a community-based tourism industry that could sustain either the cultural or natural resources of the country without substantial help from the international community under current models. The benefits of implementing protected areas, particularly those at the stricter end of the spectrum of IUCN protection, are of greater benefit to the world than to the Cameroon or indeed other developing countries. However, the pressure to develop an increasingly large network of protected lands comes from the world community. Surely this is not ethical unless we, the world community, support Cameroon, and other developing countries, to manage the world's cultural and natural biodiversity into the future for those who are, in the words of Wilkie and Carpenter [38], are debt-ridden and having to cope with high population growth. Support with developing strong sustainable community-based tourism industries would be one way to ensure that the protection of natural systems of high biodiversity value that the world community desires is achieved.

A model to achieve the dual outcomes of biodiversity conservation and poverty alleviation using community-based forestry initiatives is on an upward trajectory internationally. Such communitybased projects originated in East Asia and Central America in the 1970s. Cameroon was the first African country to introduce legislation for such community-based forestry projects in 1994, and the first community-based forest initiative commenced in 1997. By mid-2010, 457 community forests had been proposed with $20 \%$ having achieved community forest status. Gardner [48] commented that most such projects were apparently originating from community initiatives interested in conserving and managing their forests. In addition, the concept of community-based forestry has also been embraced by communities in neighbouring countries [47].

This model for community-based forestry could not be translated directly into the management of Strict Nature Reserves (1A category reserves). This is because the aim of community-based forestry is to conserve the forest's biodiversity by sustainably managing timber production [47, 48]. While the emphasis of management in Strict Nature Reserves is also on conserving the forest's biodiversity, the potential opportunities differ since use of Strict Nature Reserves limits access to the protected area (see Table 1). The opportunity exists; however, to adapt the community-based forestry model to develop community-tourism within communities, such as those that have traditionally depended on 
Bakossi Forest Park for their livelihood. Since the local villagers strongly supported protection of their lands [32], and based on the experience with community-based forestry in Cameroon and surrounding countries [47], the development of community-based tourism initiatives for the people who traditionally obtained their livelihood from Bakossi Forest Park, could serve to develop a model for such tourism more broadly.

\section{References}

1. C.R. Margules, R.L. Pressey, Nature 405, 243 (2000)

2. N. Dudley, L. Higgins-Zogib, S. Mansourian, Beyond belief: linking faiths and protected areas to support biodiversity conservation (WWF, Gland, 2005)

3. C.N. Jenkins, L. Joppa L. (2009). Expansion of the global terrestrial protected area system. Biol. Conserv. 142, 2166 (2009)

4. L.J. Wood, L. Fish J. Laughren, D. Pauly, Oryx 42, 340 (2008)

5. N. Dudley, J. D. Parrish, K.H. Redford, S. Stolton Oryx 44, 485 (2010)

of reform (World Bank Publications, Washington D.C., 2009)

6. UNEP-WCMC, Convention on biological diversity (INEP, Cambridge, 2008)

7. L. Naughton-Treves, M.B. Holland, K. Brandon, Ann. Rev. Environ.Resour. 30, 219, 2005

8. N. Dudley (Ed.), Guidelines for applying protected area management categories (IUCN, Gland, 2008)

9. N. Dudley \& J. Parrish, Closing the gap: Creating ecologically representative protected area systems (Montreal Secretariat of the CBD, Montreal, 2006)

10. M. Holdgate, The Green Web (Earthscan, London, 1999)

11. C. F. Brockman (in First World Conference on National Parks, NPS, Washington, DC, 1962)

12. H.B. Elliott (Ed). Second World Conference on National Parks, Proceedings (IUCN, Morges, 1974)

13. IUCN, Guidelines for Protected Area Management Categories. (IUCN, Gland, 1994)

14. K. Bishop, N. Dudley, A. Phillips, S. Stolton, Speaking a common language (IUCN, Paris, 2004)

15. C.N. Lambi, E.N. Ndenecho (2009). Ecology and natural resource development in the Western Highlands of Cameroon (Laangaa Research and Publishing common Initiative Group, Mankon, 2009).

16. N. Dudley, S. Stolton, (Eds) Defining protected areas (IUCN, Gland, 2008)

17. IUCN, Achieving quality: Categories (IUCN, Gland, 2014)

18. T. Mesmin, R.B. Clair, N. Appolinaire, S.M. Jean, Mapping of protected areas evolution in Cameroon from the beginning to 2000: Lesson to learn and perspectives (WWF, Morges, 2001)

19. N.S. Fonkowo, T.E. Angwafo, M. Mbida, J. Soil Sci. Environ. Manage. 2, 43 (2011)

20. M. Cheek, B.J. Pollard, I. Darbyshire, J.-M. Onana, Plants of Kupe, Mwanenguba and the Bakossi Mountains, Cameroon (Kew RBG, London, 2004)

21. Kew Gardens, A national park: The Bakossi National Park in Cameroon (conservation/researchdata/science-directory/teams/wet-tropics-africa, 2010)

22. P. Ngea, Mount Kupe and Muanenguba: Custodian of tradition and Biodiversity (WWF, Washington DC, 2011)

23. C. Wild, B.J. Morgan, A. Dixson, Int. J. Primatol. 26, 759, 2005

24. IUCN-WCMC, World database on protected areas (IUCN, Gland, 2008)

25. R. Djeukam, The wildlife law as a tool for protecting threatened species in Cameroon (MINFOF, Yaoundé, 2012)

26. E. N. Ndenecho, Local livelihoods and protected area management: Biodiversity conservation problems in Cameroon (Langaa Research and Publishing CIG, Bamenda, 2011)

27. B. Bime, Mystique: A collection of lake myths (Langaa Research and Publishing Common Initiative, Mankon, 2009)

28. B. Sharpe, Africa 68, 25, 1998)

29. L. Coad, A. Campbell, L. Miles, The costs and benefits of protected areas for local livelihood (UNEP, 2008) 
30. G. Topa, C. Megevand, A. Karsenty, The rainforests of Cameroon: Experience and evidence from a decade

31. V.B. Ebua, T.E. Agwafo, S.N. Fonkwo. Int. J. Biodiv. Conserv. 3, 631 (2011)

32. E.F. Zama, MSc. Environmental Management - Sustainable Development, Bond University (2014)

33. J. P. Brosius, J. P. Indigenous peoples and protected areas at the World Parks Congress. Conserv. Biol. 18, 609 (2004)

34. NBS, Measuring and valuing environmental impacts: An introductory guide (Network for Business Sustainability, Ontario, 2011)

35. C. Fonchingong, Gender Dev. 7, 73 (1999)

36. K.H. Redford, E. Fearn, Protected Areas and Human Livelihoods. (WCS Institute, Bronx, 2007)

37. M. Colchester, M.F. Ferrari, J. Nelson, C. Kidd, P. Zaninka, M. Venant, L. Regpala, G.T. Balawag, B. Motin, B. Lasimbang, Conservation and indigenous peoples: Assessing the progress since Durban (IUCN, Gland, 2009)

38. S. Wilkie, J.F. Carpenter, Oryx 33332 (1999)

39. S. Wilkie, J.F. Carpenter, Q. Zhang, Biodiv. Conserv. 10, 691 (2001)

40. R. Erbes, International tourism and the economy of developing countries (OECD, Paris, 1973)

41. P.U.C. Dieke, Manage. Decis. 41, 287 (2003)

42. M. Shackley, Atlas of travel and tourism development. (Butterworth-Heinemann, London, 2006)

43. A.J. Khadaroo, B. Seetanah, Tourism Econ. 13, 675 (2010)

44. P. Hele, (in Tourism: A catalyst for sustainable development in Africa (WTO, Madrid, 2002)

45. A.N. Kimbu, Int. J. Tourism Res. 13, 324 (2011)

46. J. Culverwell, Long-term recurrent costs of protected area management in Republic of Cameroon (WWF-Cameroon, Yaoundé, 1988)

47. E. Beauchamp, V. Ingram, Int. Forest. Rev. 13, 1 (2011)

48. A. Gardner, Second international workshop on participatory forestry in Africa. 153 (2002) 